\title{
CHAGAS'DISEASE: IgA, IgM AND IgG ANTIBODIES TO T. cruzi AMASTIGOTE, TRYPOMASTIGOTE AND EPIMASTIGOTE ANTIGENS IN ACUTE AND IN DIFFERENT CHRONIC FORMS OF THE DISEASE
}

Kátia S. C. PRIMAVERA (1), Eufrosina S. UMEZAWA (2), Benedito Anselmo PERES (2), Mário E. CAMARGO (2) \& Sumie HOSHINO-SHIMIZU (1)

\begin{abstract}
SUMMARY
In an attempt to find a better $\mathbf{T}$. cruzi antigen and possible immunological markers for the diagnosis of different clinical forms of Chagas'disease, amastigote and trypomastigote antigens obtained from immunosuppressed mice infected with T. cruzi ( $Y$ strain) were assessed in comparison with conventional epimastigote antigens. A total of 506 serum samples from patients with acute and with chronic (indeterminate, cardiac and digestive) forms, from nonchagasic infections, and from healthy individuals were assayed in immunofluorescence (IF) tests, to search for IgG, IgM and IgA antibodies. Amastigote proved to be the most convenient antigen for our purposes, providing higher relative efficiency indexes of 0.946, 0.871 and 0.914 for IgG, IgM and IgA IF tests, respectively. Anti-amastigote antibodies presented higher geometric mean titers (GMT) than anti-trypomastigote and anti-epimastigote. Anti-amastigote IgG antibodies were found in all forms of Chagas'disease, and predominantly IgA antibodies, in chronic digestive and in acute forms, as well as IgM antibodies, in latter forms. Thus, tests with amastigote antigen could be helpful for screening chagasic infections in blood banks. Practical and economical aspects in obtaining amastigotes as here described speak in favour of its use in developing countries, since those from other sources require more complex system of substruction, specialized personnel or equipment.
\end{abstract}

KEY WORDS: T. cruzi infections; IgG, IgM and IgA antibodies; Amastigote, Trypomastigote and Epimastigote.

\section{INTRODUCTION}

In areas in which Chagas'disease is endemic, the prevalence of chronic infections is high, and because of low parasitemia in such infections, the diagnosis is made mostly based on serological data. To the moment, T. cruzi epimastigote is utilized widely as antigen in conventional serological tests ${ }^{8}$. In recent review on assessment of different trypanosome antigens for diagnostic purpose, the reports about epimastigote antigen exceeded strikingly in number $(84 \%)$ over other

\footnotetext{
(1) Setor de Imunologia Clínica, Departamento de Análises Clínicas e Toxicológicas, Faculdade de Cièncias Farmacêuticas. Universidade de São Paulo, SP, Brasil.

(2) Instituto de Medicina Tropical de Sāo Paulo, Sāo Paulo, SP, Brasil.

Address for correspondence: Dra. Kătia S. C. Primavera. Setor de Imunologia Clínica, Faculdade de Cièncias Farmacèuticas da Universidade de São Paulo. Av. Prof. Lineu Prestes, 580 - Bloco 17, Cidade Universitária. CEP 05508 - Sāo Paulo, SP, Brasil.
} 
PRIMAVERA, K. S. C.: UMEZAWA, E. S.: PERES. B. A.: CAMARGO, M. E. \& HOSHINO SHIMIZU. S. - Chagas'disease: IgA, IgM and IgG antibodies to $\mathbf{T}$. cruzi amastigote. trypomastigote and epimastigote antigens in acute and in different chronic forms of the disease. Rev. Inst. Med. trop. S. Paulo, 32(3): 172-180, 1990.

parasite life cycle stage antigens, as trypomastigote $(9 \%)$ and amastigote $(7 \%)^{18}$. Some serological tests are also capable to provide certain information about the clinical forms of Chagas' disease, since a close positive correlation between the acute form and IgM anti-epimastigote was seen, as well as, the chronic digestive form and anti-amastigote IgA antibodies ${ }^{13 .}{ }^{19}$. Antigenic difference between life cycle stage of $T$. cruzi are known ${ }^{15}$, but trypomastigote and amastigote from vertebrate host seem to be more sensitive and adequate for the study of humoral immune response in chagasic patients ${ }^{9,10,16}$ than axenic epimastigote.

However, a better comparative study of amastigote, trypomastigote and epimastigote antigens for the diagnosis of chagasic infections was not done before. Therefore, this aspect was further explored here, as well as, an attempt to find other immunological markers for different forms of Chagas'disease (acute and chronic indeterminate, cardiac and digestive) was made, as sociating the findings on IgG, IgM and IgA antibodies with those clinical forms and with referred three life cycle stages of $\mathbf{T}$. cruzi antigens, in the immunofluorescence test.

\section{MATERIAL AND METHODS}

Serum samples: Serum samples were collec ted from 506 individuals, 225 of which had Chagas'disease, 121 of which had nonrelated infections or autoimmune disease, and 160 of which were clinically healthy. Chagasic patients included 36 with acute, 128 with chronic indeterminate, 31 with cardiac and 30 with digestive forms. All the acute infections were parasitologically confirmed by direct microscopic examinations of blood samples or xenodiagnosis. Chronic cases were classified according to clinical, electrocardiographic and radiological criteria. The indeterminate forms included patients with no clinical symptoms of the disease and a normal or only slightly abnormal electrocardiogram. The cardiac form patients had cardiomyopathy with cardiac insufficiency, cardiomegaly, and an abnormal electrocardiogram. The digestive forms included patients with radiographically detected digestive abnormalities. In 11 of the 30 cases in this group, cardiac disease was also present.
A total of 121 patients with non-related infections were studied: 10 with clinically active rubella; 20 with malaria with patent parasitemia; 19 with acute toxoplasmosis; 10 of different age groups and from areas not endemic for Chagas disease with clinically active Kala-azar; 12 with mucocutaneous leishmaniasis; 10 with recent syphilis; 32 with connective tissue diseases, including 16 with antinuclear antibodies and 16 with high-titer rheumatoid factors, and 8 with Pemphigus foleaceus. Of the clinically healthy individuals, 100 were selected in an endemic area for Chagas'disease, and 60 were blood bank donors. Negative serology [Complement fixation, IF and indirect hemagglutination (HA) tests] for Chagas'disease was seen in all nonchagasic individuals, except for a few of the patients with Kalaazar. Patients with other diseases had positive results for their respective serodiagnosis.

Serum samples were obtained from venous blood and kept at $-20^{\circ} \mathrm{C}$ until use.

Serological tests for Chagas'disease: All sera were assessed in complement fixation, IF for IgG antibody (IgG IF) and indirect HA (IHA) tests for Chagas'disease as described previous$1 y^{6}$. Serum samples from chagasic patients were also tested by an enzyme-linked immunosorbent assay for IgG antibodies ${ }^{23}$. Also, IF for IgM antibody (IgM IF) and polysaccharide IHA tests were carried out to reveal IgM antibodies in acute cases $^{13}$. To avoid interference of rheumatoid factors in the IgM IF test, we pretreated the serum samples, which were positive in a rheumatoid factor latex agglutination test (Behringwerke A. G.), with aggregated human gamma-globulin ${ }^{21}$. In the IF tests, the anti-IgA ( $\alpha$ chain specific), $\operatorname{IgM}$ ( $\boldsymbol{\mu}$ chain specific) and IgG ( $\boldsymbol{\delta}$ chain specific) fluorescent conjugate were used. All the IF test results were scored arbitrarily from $4+$ to $1+$ and doubtful or weak fluorescence considered as negative.

Parasite antigens: Parasite antigens were prepared from various T. cruzi life cycle stages. Epimastigotes antigens were obtained as described previously ${ }^{5}$. Blood stream trypomastigotes were collected from immunosuppressed mice, inoculated with trypanosome, on day 7 post infection, as reported ${ }^{19}$, and processed as for epimastigote ${ }^{5}$. Intracellular amastigotes were ta- 
PRIMAVERA, K. S. C.: UMEZAWA, E. S.; PERES, B. A.; CAMARGO, M. E. \& HOSHINO SHIMIZU, S. - Chagas'disease: $\operatorname{Ig} A$, IgM and IgG antibodies to $T$. cruzi amastigote, trypomastigote and epimastigote antigens in acute and in different chronic forms of the disease. Rev. Inst. Med. trop. S. Paulo, 32(3): 172-180, 1990.

ken from liver and spleen of infected mice, puri fied by two-step discontinuous gradient centrifugation as described previously ${ }^{1}$ and also processed as described for epimastigotes ${ }^{5}$.

For the evaluation of each of studied antigens, diagnostic performance indexes were estimated in terms of relative sensitivity, specificity and efficiency according to GALEN \& GAMBI$\mathrm{NO}^{11}$ and the cutoffs taken at their highest efficiency indexes. To calculate geometric mean titers (GMT) of IgG, IgM and IgA antibodies and standard deviations ( $\mathrm{Sd}$ ), the titers $(\mathrm{T})$ were transformed to $\log _{2}\left(\log _{2} 0,4 \mathrm{~T}\right)$ according to WHITE ${ }^{24}$.

\section{RESULTS}

Serum samples from chagasic patients were all reactive in the enzyme-linked immunosorbent assay and most were reactive in the three other conventional tests, IgG IF, IHA and complement fixation, or at least in two of these. The 36 serum samples from patients with acute Chagas'disease were reactive in both IgM IF and polysaccharide IHA tests, or in one of these, as well. Samples from patients with other diseases were non-reactive, except 2 cases of Kala-azar and 5 from healthy individuals, in which the titers were low $(\leq 80)$.

To define possible immunological marker for different forms of Chagas'disease, as well as to verify the better antigen for diagnostic purpose, cutoff titers were established for each test to distinguish, with highest efficiency, each form of Chagas'disease from other forms of the same disease, other infections, and normal individuals. Group of patients with acute forms were studied independently from the group with chronic digestive forms in IgA IF test. For the study of former group, the latter was not included, and conversely, for the study of latter group, the former was excluded, since, although acute infections have IgA-reactive antibodies, they can be distinguished from patients with other Chagas' disease, because they have anti-t. cruzi IgM antibodies in their sera.

Table 1 indicates sensitivity, specificity, and efficiency indexes for selected cutoffs. In general, IF tests with amastigote antigens provided higher efficiency values, followed by tests with trypomastigote, except in IgM IF test.

\section{TABLE 1}

Diagnostic performance indexes of IF tests for IgG, IgM and IgA antibodies with $\mathbf{T}$. cruzi amastigote, trypomastigote and epimastigote antigens in patients with acute and with chronic indeterminate, cardiac and digestive forms of Chagas'disease

\begin{tabular}{|c|c|c|c|c|c|c|}
\hline $\begin{array}{c}\text { IF } \\
\text { Test }\end{array}$ & $\begin{array}{l}\text { Clinical } \\
\text { Form }\end{array}$ & Antigen & Sensitivity & Specificity & Efficiency & $\begin{array}{c}\text { Cutoff } \\
\text { Titer } \\
\left(\log _{2}\right)\end{array}$ \\
\hline \multirow[t]{3}{*}{ IgG } & \multirow{3}{*}{$\begin{array}{l}\text { Acute } \\
\text { and Chronic }\end{array}$} & Amastigote & 0.938 & 0.952 & 0.946 & 8 \\
\hline & & Trypomastigote & 0.871 & 0.882 & 0.877 & 5 \\
\hline & & Epimastigote & 0.804 & 0.974 & 0.897 & 5 \\
\hline \multirow[t]{3}{*}{$\operatorname{IgM}$} & \multirow[t]{3}{*}{ Acute } & Amastigote & 0.861 & 0.872 & 0.871 & 9 \\
\hline & & Trypomastigote & 0.889 & 0.463 & 0.518 & 5 \\
\hline & & Epimastigote & 0.861 & 0.839 & 0.842 & 6 \\
\hline \multirow[t]{3}{*}{$\operatorname{Ig} \mathrm{A}$} & \multirow[t]{3}{*}{ Acute } & Amastigote & 0.611 & 0.913 & 0.868 & 10 \\
\hline & & Trypomastigote & 0.472 & 0.778 & 0.733 & 3 \\
\hline & & Epimastigote & 0.194 & 0.662 & 0.593 & 1 \\
\hline \multirow[t]{3}{*}{$\operatorname{Ig} \mathrm{A}$} & Chronic & Amastigote & 0.923 & 0.913 & 0.914 & 10 \\
\hline & \multirow[t]{2}{*}{ Digestive } & Trypomastigote & 0.192 & 0.778 & 0.712 & 3 \\
\hline & & Epimastigote & 0.038 & 0.662 & 0.592 & 1 \\
\hline
\end{tabular}


PRIMAVERA, K. S. C.: UMEZAWA, E. S.; PERES, B. A.; CAMARGO, M. E. \& HOSHINO SHIMIZU, S. - Chagas'disease: IgA. IgM and IgG antibodies to $T$. cruzi amastigote, trypomastigote and epimastigote antigens in acute and in different chronic forms of the disease. Rev. Inst. Med. trop. S. Paulo, 32(3): 172-180, 1990.

Table 2,3 and 4 present the reactivities for serum samples from patients in the several groups studied in relation to the established $\mathrm{cu}$ toffs for IgG, IgM and IgA IF tests, respectively.

In IgG IF test with epimastigote, poor re sults $(37 \%)$ were obtained with serum samples from digestive forms of Chagas'disease. In acute chagasic infections, positivity was high for IgM IF test with any of three studied antigens. Also in serum samples from indeterminate forms, positivities of $23 \%, 45 \%$ and $32 \%$ were seen for IgM IF test with amastigote, trypomastigote and epimastigote antigens, respectively.

In IgA IF test with amastigote, positivity was high in digestive form and in acute infection. However in indeterminate forms, positivity of $21 \%$ was observed, and in cardiac forms, $16 \%$ Higher nonspecific reactivities are seen in IgG and IgM IF tests with trypomastigote and in IgA IF with trypomastigote and epimastigote.

As illustrated in table 5, anti-amastigote IgG, IgM and IgA antibodies presented higher GMT in relation to anti-trypomastigote and anti-epimastigote. Titers of anti-amastigotes IgG antibodies ranged from $64 \times 10$ to $20 \times 10^{6}$; of $\mathrm{IgM}$ antibodies, from $12 \times 10^{2}$ to $20 \times 10^{6}$ and of $\operatorname{IgA}$ antibodies in sera either from acute or digestive forms, from $25 \times 10^{2}$ to $26 \times 10^{5}$.

\section{DISCUSSION}

In the present study, two aspects were investigated: the first dealing with $\mathbf{T}$. cruzi antigens (amastigote, trypomastigote and epimastigote) which might provide better diagnostic performance, in a comparative study by IF test, and the second, with immunological markers for dif-

TABLE 2

Positivity in IF tests for IgG antibodies with amastigote, trypomastigote and epimastigote antigens in serum samples from chagasic (225) and nonchagasic patients (272)

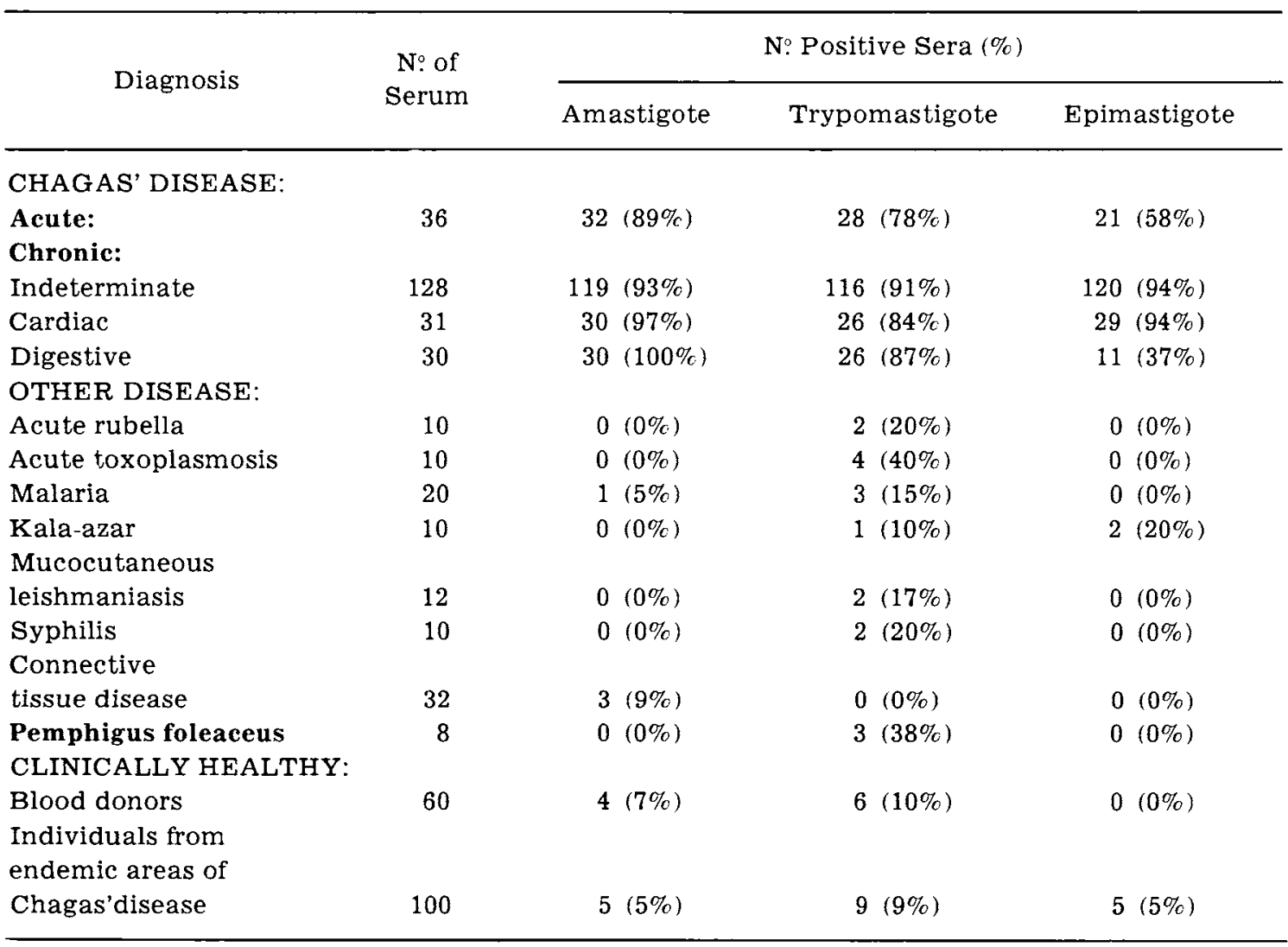


PRIMAVERA, K. S. C.; UMEZAWA, E. S.; PERES. B. A.; CAMARGO, M. E. \& HOSHINO SHIMIZU, S. - Chagas'disease: IgA, IgM and IgG antibodies to $T$. cruxi amastigote, trypomastigote and epimastigote antigens in acute and in different chronic forms of the disease. Rev. Inst. Med. trop. S. Paulo, 32(3): 172-180, 1990.

TABLE 3

Positivity in IF tests for IgM antibodies with amastigote, trypomastigote and epimastigote antigens in serum samples from chagasic (149) and nonchagasic patients (129)

\begin{tabular}{|c|c|c|c|c|}
\hline \multirow{2}{*}{ Diagnosis } & \multirow{2}{*}{$\begin{array}{l}\text { N: of } \\
\text { Serum }\end{array}$} & \multicolumn{3}{|c|}{ No Positive Sera $(\%)$} \\
\hline & & Amastigote & Trypomastigote & Epimastigote \\
\hline \multicolumn{5}{|l|}{ CHAGAS' DISEASE: } \\
\hline $\begin{array}{l}\text { Acute: } \\
\text { Chronic: }\end{array}$ & 36 & $31(86 \%)$ & $32(89 \%)$ & $31(86 \%)$ \\
\hline Indeterminate & 56 & $13(23 \%)$ & $25(45 \%)$ & $18(32 \%)$ \\
\hline Cardiac & 31 & $0(0 \%)$ & $9(29 \%)$ & $4(13 \%)$ \\
\hline Digestive & 26 & $2(8 \%)$ & $8(31 \%)$ & $3(12 \%)$ \\
\hline \multicolumn{5}{|l|}{ OTHER DISEASE: } \\
\hline Acute rubella & 10 & $0(0 \%)$ & $9(90 \%)$ & $0(0 \%)$ \\
\hline Acute toxoplasmosis & 19 & $4(21 \%)$ & $12(63 \%)$ & $3(16 \%)$ \\
\hline Malaria & 10 & $1(10 \%)$ & $8(80 \%)$ & $0(0 \%)$ \\
\hline Kala-azar & 10 & $0(0 \%)$ & $3(30 \%)$ & $1(10 \%)$ \\
\hline \multicolumn{5}{|l|}{ Mucocutaneous } \\
\hline leishmaniasis & 10 & $2(20 \%)$ & $10(100 \%)$ & $0(0 \%)$ \\
\hline Syphilis & 10 & $1(10 \%)$ & $10(100 \%)$ & $5(50 \%)$ \\
\hline \multicolumn{5}{|l|}{ Connective } \\
\hline tissue disease & 10 & $0(0 \%)$ & $2(20 \%)$ & $0(0 \%)$ \\
\hline \multicolumn{5}{|c|}{ CLINICALLY HEALTHY: } \\
\hline Blood donors & 30 & $2(7 \%)$ & $17(57 \%)$ & $2(7 \%)$ \\
\hline $\begin{array}{l}\text { Individuals from } \\
\text { endemic areas of }\end{array}$ & & & & \\
\hline Chagas'disease & 20 & $6(30 \%)$ & $17(85 \%)$ & $3(15 \%)$ \\
\hline
\end{tabular}

ferent clinical forms of Chagas'disease (acute and chronic indeterminate, cardiac and diges tive forms).

Thus, higher diagnostic performance indexes were obtained for IgG, IgM and IgA IF tests with amastigote antigens, in the study of different clinical forms of Chagas'disease, in relation to the tests with trypomastigote and epimas tigote. Amastigote antigens as prepared here from $\mathbf{T}$. cruzi infected mice were not evaluated before in serological tests for diagnostic purpose.

Cutoff titers vary according to the type of antigen and panel of sera selected from populations for the standardization of tests. Inasmuch as in this work many nonrelated infections were included, the cutoff titers are in general higher in comparison with those reported. Thus, the cutoff for IgG IF with amastigote stipulated here is higher than those reported for tests with amastigote from cell cultures ${ }^{3}$ 9. 22 and with amastigote of skeletal muscle sections from infected mouse with T. cruzi $^{10}$. Also, in the same test with trypomastigote and epimastigote, the titers taken as cutoffs are higher than those reported ${ }^{2}$ $3,5,20,22$. Even in IgM IF test with epimastigote, the cutoff titer is slightely higher than that determined before ${ }^{13}$. Nevertheless, in IgA IF with amastigote, the cutoff titer used is similar to that stablished in the previous work ${ }^{19}$.

Titers of anti-amastigote $\operatorname{IgG}, \operatorname{IgM}$ and $\operatorname{Ig} A$ antibodies in sera from group of patients studied are also higher, as well as their GMT. In general, the anti-amastigote IgG antibody titers varied in similar range to the titers of anti-amastigote of skeletal muscle sections from infected mou$\mathrm{se}^{10}$. These high reactivity of antibody to amastigote antigen was verified to be specific with 
PRIMAVERA, K. S. C.; UMEZAWA, E. S.; PERES, B. A.; CAMARGO, M. E. \& HOSHINO SHIMIZU, S. - Chagas'disease: IgA, IgM and IgG antibodies to T. cruzi amastigote, trypomastigote and epimastigote antigens in acute and in different chronic forms of the disease. Rev. Inst. Med. trop. S. Paulo, 32(3): 172-180, 1990.

TABLE 4

Positivity in IF tests for IgA antibodies with amastigote, trypomastigote and epimastigote antigens in serum samples from chagasic (149) and nonchagasic patients (120)

\begin{tabular}{|c|c|c|c|c|}
\hline \multirow{2}{*}{ Diagnosis } & \multirow{2}{*}{$\begin{array}{l}\text { N: of } \\
\text { Serum }\end{array}$} & \multicolumn{3}{|c|}{ No Positive Sera $(\%)$} \\
\hline & & Amastigote & Trypomastigote & Epimastigote \\
\hline \multicolumn{5}{|l|}{ CHAGAS' DISEASE: } \\
\hline Acute: & 36 & $22(61 \%)$ & $17(47 \%)$ & $7(19 \%)$ \\
\hline \multicolumn{5}{|l|}{ Chronic: } \\
\hline Indeterminate & 56 & $12(21 \%)$ & $7(13 \%)$ & $15(27 \%)$ \\
\hline Cardiac & 31 & $5(16 \%)$ & $1(3 \%)$ & $10(32 \%)$ \\
\hline Digestive & 26 & $24(92 \%)$ & $5(19 \%)$ & $1(4 \%)$ \\
\hline \multicolumn{5}{|l|}{ OTHER DISEASE: } \\
\hline Acute rubella & 10 & $0(0 \%)$ & $2(20 \%)$ & $0(0 \%)$ \\
\hline Acute toxoplasmosis & 10 & $0(0 \%)$ & $2(20 \%)$ & $1(10 \%)$ \\
\hline Malaria & 10 & $0(0 \%)$ & $0(0 \%)$ & $0(0 \%)$ \\
\hline Kala-azar & 10 & $0(0 \%)$ & $0(0 \%)$ & $1(10 \%)$ \\
\hline \multicolumn{5}{|l|}{ Mucocutaneous } \\
\hline leishmaniasis & 10 & $0(0 \%)$ & $7(70 \%)$ & $0(0 \%)$ \\
\hline Syphilis & 10 & $0(0 \%)$ & $9(90 \%)$ & $10(100 \%)$ \\
\hline \multicolumn{5}{|l|}{ Connective } \\
\hline tissue disease & 10 & $0(0 \%)$ & $3(30 \%)$ & $4(40 \%)$ \\
\hline \multicolumn{5}{|c|}{ CLINICALLY HEALTHY: } \\
\hline Blood donors & 30 & $0(0 \%)$ & $11(37 \%)$ & $26(87 \%)$ \\
\hline \multicolumn{5}{|l|}{$\begin{array}{l}\text { Individuals from } \\
\text { endemic areas of }\end{array}$} \\
\hline Chagas'disease & 20 & $1(5 \%)$ & $4(20 \%)$ & $3(15 \%)$ \\
\hline
\end{tabular}

TABLE 5

Geometric mean titers (GMT) and standard deviations (sd), estimated for anti-amastigote, anti-trypomastigote and anti-epimastigote antibodies from patients with acute (A) and chronic indeterminate (CI), cardiac (CC) and digestive (CD) forms of Chagas'disease, in IF tests for IgG, IgM and IgA antibodies

\begin{tabular}{|c|c|c|c|c|c|c|}
\hline \multirow{3}{*}{$\begin{array}{l}\text { IF } \\
\text { test }\end{array}$} & \multirow{3}{*}{ Antigen } & \multicolumn{4}{|c|}{$\log _{2}$ GMT (sd) } & \multirow{3}{*}{$\begin{array}{c}\text { Nonchagasic } \\
\text { infection }\end{array}$} \\
\hline & & \multicolumn{4}{|c|}{ Chagas's disease } & \\
\hline & & A & CI & $\mathrm{CC}$ & $\mathrm{CD}$ & \\
\hline \multirow[t]{3}{*}{ IgG } & Amastigote & $11.3(4.0)$ & $11.4(2.5)$ & $11.1(2.4)$ & $11.9(2.5)$ & $4.4(2.0)$ \\
\hline & Trypomastigote & $6.7(2.8)$ & $6.9(1.9)$ & $6.1(2.0)$ & $7.0(2.2)$ & $2.1(1.9)$ \\
\hline & Epimastigote & $4.9(1.7)$ & $7.2(1.5)$ & $6.8(1.3)$ & $4.0(2.6)$ & $1.8(1.4)$ \\
\hline \multirow[t]{3}{*}{$\operatorname{IgM}$} & Amastigote & $12.6(4.4)$ & $6.2(3.5)$ & $4.5(2.4)$ & $5.7(3.0)$ & $6.1(2.7)$ \\
\hline & Trypomastigote & $7.4(2.7)$ & $3.5(2.9)$ & $2.7(3.1)$ & $2.8(2.7)$ & $5.4(2.3)$ \\
\hline & Epimastigote & $7.2(1.6)$ & $3.3(3.0)$ & $2.2(2.6)$ & $2.7(2.3)$ & $3.0(2.3)$ \\
\hline \multirow[t]{3}{*}{$\operatorname{Ig} A$} & Amastigote & $10.4(4.1)$ & $7.3(2.7)$ & $7.7(1.9)$ & $12.6(3.8)$ & $3.5(2.2)$ \\
\hline & Trypomastigote & $3.2(3.0)$ & $1.2(1.6)$ & $0.7(0.5)$ & $1.3(2.0)$ & $2.0(2.0)$ \\
\hline & Epimastigote & $1.2(1.8)$ & $1.2(1.6)$ & $1.4(1.8)$ & $0.5(0.1)$ & $1.3(1.4)$ \\
\hline
\end{tabular}


PRIMAVERA, K. S. C.: LMEZAWA, E. S.: PER.ES, B. A : CAMARGO. M. E. \& HOSHINO SHIMIZU. S. - Chagas disease IgA. IgM and IgG antibodies to T. cruzi amastigote. trypomastigote and epimastigote antigens in acute and in different chronic forms of the disease. Rev. Inst. Med. trop. S. Paulo. 32(3): 172 180. 1990.

no interference of mouse tissue components in our previous work ${ }^{19}$.

In IgG IF test with amastigote antigens, positivities found for different forms of Chagas'disease are all higher, whereas in test with conventional epimastigote, the positivity was low only for digestive form of Chagas'disease. Hence misleading diagnoses of Chagas'disease among patients with digestive impairment seem to be frequent in endemic areas.

The sensitivity of IgG IF test with trypomastigotes was lower than that reported by $\mathbf{S A}$ $\mathrm{DUN}^{20}$, but its specificity laid within the values obtained by some investigators ${ }^{5,20}$.

Positive correlation between the acute form of Chagas'disease and IgM antibodies to amastigote, to trypomastigote and to epimastigote were found, and these findings were expected, since anti-epimastigote IgM antibodies were detected previously ${ }^{13}$ in acute infections. The relevant finding however was the detection of $\operatorname{Ig} A$ antibodies to amastigote antigens, in analogous way to those non-related acute infections, in which this class of specific antibodies are demonstrated to have pathogenic significance and diagnostic value ${ }^{4,12,18}$. Positivities in IgM and IgA IF tests should be improved in acute chagasic infections seeing that in several negative cases, the antibodies are possibly present in low titers, similarly to IgM antibodies in acute toxoplas$\operatorname{mosis}^{17}$. Therefore, we are trying now to remove IgG antibodies which might be interfering, by mean of well known procedures ${ }^{7}$ to enhance the reactivities of IgM and IgA antibodies in IF tests.

Trypomastigotes rather than epimastigotes gave higher nonspecific results in IgM and in IgA IF tests, possibly by ubiquitous antigenic determinants common to Treponema pallidum, Leishmania sp amastigotes, and other microorganisms, but absent from $\mathbf{T}$. cruzi amastigotes.

As verified previously ${ }^{19}$, anti-amastigote $\operatorname{Ig} \mathrm{A}$ antibodies correlated closely with chronic digestive forms of Chagas'disease, and these might be an early serological signal of mucosa lesions when revealed in chronic disease, in the absence from IgM antibodies. In 12 patients with indeterminate forms, IgA antibodies were found, and
7 of these had also IgM antibodies. It is possible they were still in acute phase of infection with no defined symptoms and, due to their positivity in conventional serology, were considered as in determinate forms. These 12 cases were all from Mambaí (GO), an endemic area for Chagas'disease, where light infections can not be ruled out. As to the remainders 5 , as well as 5 from cardiac forms in which IgA antibodies were found, with no IgM, have to be closely monitored to investigate whether the disease will progress with the onset of digestive disturbances.

In brief, the amastigote proved to be more sensitive antigen to detect $\operatorname{IgG}, \operatorname{Ig} M$ and $\operatorname{Ig} A$ antibodies from different forms of Chagas'disea se and this would be helpful for screening chaga sic infections in blood banks. As to the immuno logical markers, IgA antibodies suggest to be correlated with acute infections along with IgM antibodies.

Amastigote as here obtained is more convenient and less costly for developing countries, since in most laboratories which produces their own antigens has animal quarter facilities rather than specialized personnel and substruction for cell culture, or then equipment such as cryostat to provide tissue sections of infected animal with T. cruzi as antigenic substrate.

\section{RESUMO}

Doença de Chagas: anticorpos IgG, IgM e IgA contra antígenos de am astigota, tripomastigota e epimastigota de $T$. cruzi em formas agudas e em diferentes formas crônicas da doença.

Com o intúito de se aperfeiçoar o diagnóstico sorológico das diferentes formas clínicas da doença de Chagas, foram estudados antigenos de formas amastigota e tripomastigota, obtidas de camundongos imunossuprimidos infectados com cepa $Y$ de $\mathbf{T}$. cruzi, em comparaçāo com o de epimastigota convencionalmente utilizado. Um total de 506 amostras de soro de pacientes chagásicos com formas aguda e cronicas (indeterminada, cardiaca e digestiva), de individuos com infecçōes nāo relacionadas e de indivíduos sadios foi analisado por reação de imunofluorescência, para deteç̧āo de anticorpos IgG, IgM e IgA. O antígeno de amastigota apresentou os 
PRIMAVERA, K. S. C.; UMEZAWA, E. S.; PERES, B. A.; CAMARGO, M. E. \& HOSHINO SHIMIZU, S. — Chagas'disease: IgA, IgM and IgG antibodies to T. cruzi amastigote, trypomastigote and epimastigote antigens in acute and in different chronic forms of the disease. Rev. Inst. Med. trop. S. Paulo, 32(3): 172-180, 1990.

mais altosíndices de eficiência relativa em testes de IF IgG $(0,946)$, IF IgM $(0,871)$ e IF IgA $(0,914)$, mostrando ser mais conveniente para a finalidade proposta. Anticorpos anti-amastigota apresentaram médias geométricas de títulos mais altas que anti-tripomastigota e anti-epimastigota. Anticorpos IgG anti-amastigota-foram encontrados em todas as formas clínicas da doença de Chagas, e anticorpos $\operatorname{Ig} A$ foram encontrados predominantemente em formas crônicas digestivas e em formas agudas, além de anticorpos IgM nestas últimas formas. Portanto, testes com antigeno amastigota poderiam ser úteis para a triagem de indivíduos chagásicos em bancos de sangue. Aspectos práticos e econômicos na obtenção de amastigotas, conforme descrito neste trabalho favorecem seu uso em países em desenvolvimento, já que o antígeno obtido por meio de outras fontes requer uma infraestrutura mais complexa, equipamentos e pessoal especializados.

\section{ACKNOWLEDGEMENTS}

This work was supported by Conselho de Desenvolvimento Científico e Tecnológico (CNPq - PIDE VI), and by Fundação de Amparo à Pesquisa do Estado de São Paulo.

We thank Rosely dos Santos Malafronte for technical assistance and Maria Inês Cardillo Se rafim for helping in the preparation of the manuscript.

\section{REFERENCES}

1. ABRAHAMSON, I. A.; KATZIN, A. M. \& MILDER, R. V. - A method for isolating $T$. cruxi amastigotes from spleen and liver using two-step discontinuous gradient centrifugation. J. Parasit., 69: 437-439, 1983.

2. ARAUJO, F. G. \& BATISTA, S. - Observaçōes sobre os testes de fixação do complemento e imunofluorescência indireta em doença de Chagas. Rev. Inst. Med. trop. S. Paulo, 11: 104-110, 1969 .

3. ARAUJO, F. G. \& GUPTILL, D. - Use of antigen preparations of the amastigote stage of $T$. cruzi in the serology of Chagas'disease. Amer. J. trop. Med. Hyg., 33: 362-371, 1984.

4. BIAGIONI, L.; SOUZA, M. J.: CHAMMA, L. G.; MENDES, R. P.: MARQUES, S. A.; MOTA, N. G. S. \& FRANCO, M. - Serology of paracoccidioidomycosis. II - Correlation between class-specific antibodies and clinical forms of the disease. Trans. roy. Soc. trop. Med. Hyg., 78: $617-621,1984$.

5. CAMARGO, M. E. - Fluorescent antibody test for the scrodiagnosis of American trypanosomiasis technical mo dification employing preserved culture forms of $\mathbf{T}$. cruzi in slide test. Rev. Inst. Med. trop. S. Paulo, 8: 227-234, 1966.

6. CAMARGO, M. E.; HOSHINO-SHIMIZU, S. \& UMEZA WA, E.S. - Further evaluation of the "IMT-Chagas flocculation test". Comparison with complement fixation, hemagglutination and immunofluorescence tests. Rev. Inst. Med. trop. S. Paulo, 17: 230-235, 1975.

7. CAMARGO, M. E.; LESER, P. G. \& ROCCA, A. - Detec tion of IgM anti-Toxoplasma antibodies in acute acquired and congenital toxoplasmosis after protein A treatment of serum. Rev. Inst. Med. trop. S. Paulo, 25: 201-206, 1983.

8. CAMARGO, M. E. \& TAKEDA, G. K. F. - Diagnóstico de laboratório. In: BRENNER. Z. \& ANDRADE, Z.. ed. Trypanosoma cruzi e doença de Chagas. Rio de Janeiro, Guanabara Koogan, 1979. p. 175-198.

9. CERISOLA, J.A.; ALVAREZ, M.; BOCK, M. \& WEGNER, D. - A comparison of a new antigen from amastigotes of $\mathbf{T}$. cruzi and an antigen from epimastigotes for the diag nosis of Chagas'disease by the indirect immunofluorescence test. Rev. Inst. Med. trop. S. Paulo, 13: 162-166 1971.

10. COSSIO, P. M.; CASANOVA, M.B.; GONZALES-CAPPA S.; FERNÁNDEZ, L. \& ARANA, R. M. - El posible uso de amastigotes tisulares de $T$. cruzi para pruebas seroló gicas de inmunofluorescencia. Medicina (B. Aires), 43: $737-738,1983$

11. GALEN, R. S. \& GAMBINO, S. R. - Beyond Normality: predictive value and efficiency of medical diagnosis. New York, John Wiley, 1975. p. 30-40.

12. GUIMARÁES, M. C. S.; FERREIRA, A. W.; CARVALHO, M. D. de; CELESTE, B. J.; CUCÉ, L. C. \& BELDA Ir., W. - Antileishmania IgA immunoenzymatic assay in mucocutaneous leishmaniasis. Rev.Inst. Med.trop.S.Paulo, 26: 353-356, 1984.

13. HOSHINO-SHIMIZU, S.; CAMARGO, M. E. \& NAGAS$\mathrm{SE}, \mathrm{T} . \mathrm{K}$. - A stable polysaccharide-hemagglutination reagent for the diagnosis of acute or recent $T$. cruzi infections. Rev. Inst. Med. trop. S. Paulo, 20: 208-212, 1978.

14. KANAMURA, H. Y.; HOSHINO-SHIMIZU; S.; CAMARGO, M. E. \& SILVA, L. C. - Class specific antibodies and fluorescent staining patterns in acute and chronic forms of schistosomiasis mansoni. Amer. J. trop. Med. Hyg., 28: 242-248, 1979.

15. KLOETZEL, J ; CAMARGO, M. E. \& GIOVANINI, V. L. - Antigenic differences among epimastigotes, amastigotes and trypomastigotes of Trypanosoma cruzi. J.Parasit., 22: 259-261, 1975 .

16. KRETTLI, A. U. \& BRENNER, Z. - Resistance against T. cruzi associated to anti-living trypomastigote antibodies. J. Immunol., 128: 2009-2012, 1982. 
PRIMAVERA, K. S. C.; UMEZAWA, E. S.; PERES, B, A.; CAMARGO, M. E. \& HOSHINO SHIMIZU, S. - Chagas'disease: IgA, IgM and IgG antibodies to $T$. cruzi amastigote, trypomastigote and epimastigote antigens in acute and in different chronic forms of the disease. Rev. Inst. Med. trop. S. Paulo, 32(3): 172-180, 1990.

17. MINEO, J. R.; CAMARGO, M. E.; FERREIRA, A. W. \& ALMEIDA, G. - Pesquisa de anticorpos IgM anti-Toxoplasma gondii por meio de técnica imunoenzimática re versa. Rev. Inst. Med. trop. S. Paulo, 28: 6-11, 1986.

18. PRIMAVERA, K. S. C. - Eficiência dos antigenos das formas evolutivas do $T$. cruzi para deteç̧āo de anticorpos das classes $A, M$ e $\mathrm{G}$ nas diferentes formas elínicas de infecçáo chagásica pela reaçáo de imunofluorescência indireta. Sāo Paulo, 1985 (Tese de Doutoramento - Instituto de Ciências Biomédicas da Universidade de São Pau10).

19. PRIMAVERA, K. S. C.; HOSHINO-SHIMIZU, S.; UMEZAWA, E.S.; PERES, B. A.; MANIGOT, D. A. \& CAMAR GO, M. E. - Immunoglobulin A antibodies to Trypanosoma cruzi antigens in digestive forms of Chagas'disease. J. clin. Microbiol., 26: 2101-2104, 1988.

20. SADUN, E. H.; DUXBURY, E. P.; WILLIAM, J. S. \& ANDERSON, R. I. - Fluorescent antibody test for the serodtagnosis of African and American trypanosomiasis in man. J. Parasit., 49: 385-388, 1983.
21. TOTH, C. A.; POHL, D. \& AGNELLO, V. - Methods for detection of immune complexes utilizing $\mathrm{Cl}_{\mathrm{q}}$ or rheuma toid factors. In: ROSE, N. R.; FRIEDMAN, H. \& FAHEY, J. L., ed. Manual of clinical laboratory immunology. 3rd ed., Washington, American Society for Microbiology, 1986. p. 204-210.

22. UMEZAWA, E. S. - Isolamento e obtençāo do T. cruzi em cultivos celulares. Sāo Paulo, 1980 (Dissertaçāo de Mestrado - Instituto de Ciências Biomédicas da Universidade de São Paulo).

23. VOLLER, A.; DRAPPER, D. C.; BIDWELL, D. E. \& BARTLETT, A. - Microplate enzyme-linked immunosorbent assay for Chagas'disease. Lancet, 1: 426-429, 1975.

24. WHITE, C. - Statistical methods in serum surveys. In PAUL, J. R. \& WHITE, C., ed. Serological epidemiology. New York, Academic Press, 1973. p. 19-31.

Recebido para publicação em 25/9/1989. 